Abstractacta Iranica

Revue bibliographique pour le domaine irano-aryen

Volume 27 | 2006

Comptes rendus des publications de 2004

«The Masjid-i Malik in Kirman ». Iran, 42, (2004), pp. 137-157.

\title{
Monik Kervran
}

\section{(2) OpenEdition}

1 Journals

Édition électronique

URL : http://journals.openedition.org/abstractairanica/6102

DOI : 10.4000/abstractairanica.6102

ISSN : 1961-960X

\section{Éditeur :}

CNRS (UMR 7528 Mondes iraniens et indiens), Éditions de l'IFRI

\section{Édition imprimée}

Date de publication : 15 mai 2006

ISSN : 0240-8910

\section{Référence électronique}

Monik Kervran, « «The Masjid-i Malik in Kirman ». Iran, 42, (2004), pp. 137-157. », Abstracta Iranica [En ligne], Volume 27 | 2006, document 234, mis en ligne le 02 janvier 2007, consulté le 25 septembre 2020. URL : http://journals.openedition.org/abstractairanica/6102 ; DOI : https://doi.org/10.4000/ abstractairanica.6102

Ce document a été généré automatiquement le 25 septembre 2020.

Tous droits réservés 


\section{« The Masjid-i Malik in Kirman ». Iran, 42, (2004), pp. 137-157.}

\section{Monik Kervran}

L'A. reconstitue, avec beaucoup de finesse, l'histoire de cette mosquée, la plus grande et la plus ancienne de Kermān, située au sud-est de la ville, dans le quartier Šāh 'Adil, par référence au souverain saljuqide Tūrān Šāh qui gouverna le Kermān entre 477/1084 et 490/1098. La mosquée subit au cours des siècles de nombreuses transformations dont bien des épisodes sont mal connus. Il semble qu'à l'origine ce fut une petite mosquée (namāz Hāana), le šabistān de l'Imām Ḥasan, érigé selon la tradition locale à la suite d'une visite à cet endroit du $2^{\mathrm{e}}$ imâm shi'ite vers 21 ou 23 de l'hégire. D'abord construits en briques crues ( $33 \mathrm{~cm}$ de côté et $10 \mathrm{~cm}$ d'épaisseur), les murs de ce bâtiment furent plus tard renforcés par des briques cuites et pourvus d'un beau miḥrāb sculpté, probablement à l'époque où était érigé, tout à côté, l'īwān-miḥrāb qui porte le nom de son commanditaire, Tūrān Šāh. Peu après, dans une salle de prière située au dessus du šabistān, trois miḥrābs très richement décorés furent aménagés côte à côte, sans doute dans les dernières années du $5^{\mathrm{e}} / 11^{\mathrm{e}}$ ou les premières $\mathrm{du} 6^{\mathrm{e}} / 12^{\mathrm{e}}$ siècles.

2 Les autres parties de la mosquée sont pour certaines de l'époque Safavide, les trois īwān s est, sud et nord-ouest datent de l'époque Qajar et les revêtements des façades sur cour sont contemporains.

\section{INDEX}

Thèmes : 5.1. Monde iranophone 
AUTEURS

MONIK KERVRAN

CNRS - Paris 